\title{
The Ability Free Radical Binding of Dengen's Stem Bark Extract (Dillenia serrata) From Luwu District Indonesia
}

\author{
Santi Sinala*, Ismail Ibrahim, Alfrida Monica Salasa
}

Santi Sinala*, Ismail Ibrahim, Alfrida Monica Salasa

Department of Pharmacy Poltekkes Kemenkes Makassar, Baji Gau No.10, Mamajang, Makassar, INDONESIA.

\section{Correspondence}

\section{Santi Sinala}

Department of Pharmacy, Poltekkes Kemenkes Makassar, Baji Gau No.10, Mamajang, Makassar, INDONESIA.

Phone no: +6285255918123;

E-mail: santisinala@poltekkes-mks.ac.id History

- Submission Date: 24-03-2020;

- Review completed: 19-04-2020;

- Accepted Date: 04-05-2020.

DOI : 10.5530/pj.2020.12.184

Article Available online http://www.phcogj.com/v12/i6

\section{Copyright}

(C) 2020 Phcogi.Com. This is an openaccess article distributed under the terms of the Creative Commons Attribution 4.0 International license.

\section{ABSTRACT}

Degenerative diseases such as cancer, heart disease is one of the diseases caused by free radicals. Dengen (Dillenia serrata) is one of Indonesia's endemic local plants that has the potential to bind free radicals. So far, only limited to the use of fruit and consumed directly. This study aims to determine the ability of dengen stem bark extract to bind to free radicals expressed in IC50. In the initial research, the total content of polyphenols in dengen stem bark extract was $444.8 \mathrm{mg} \mathrm{GAE} \mathrm{/} \mathrm{g}$ or $44.48 \%$. Dengen stem bark is extracted by maceration using $70 \%$ ethanol solvent. Antioxidant activity was calculated based on IC50 (Inhibition Concentration) values using the DPPH method, and measured at a wavelength of $516 \mathrm{~nm}$. Ethanol extract of dengen bark is made in 5 concentration series, namely 10 ppm, 20 ppm, $30 \mathrm{ppm}, 40 \mathrm{ppm}$ and $50 \mathrm{ppm}$. Ethanol extract of dengen bark has a very active antioxidant activity with an IC50 value of $48.33 \mathrm{ppm}$. Whereas for comparison vitamin $\mathrm{C}$ has an IC50 value of $15.448 \mathrm{ppm}$. From the results, it can be concluded that the ethanol extract of dengen bark has the ability to bind free radicals with IC50 48.33 ppm

Key words: Dengen, Ethanol Bark Extract, Free Radicals, IC50.

\section{INTRODUCTION}

Non-communicable diseases or degenerative diseases are diseases that cause damage to body organs. Some degenerative diseases that are mostly suffered are diabetes mellitus, hypertension, cancer, coronary heart disease (CHD), cardiovascular disease and lung disease. Based on WHO data in 2008 there were 57 million deaths in the world, mostly caused by non-communicable diseases. Degenerative diseases not only kill old people, they can also kill young people. ${ }^{1}$

One of the causes of degenerative diseases is free radicals. Free radicals are active electrons in the body that do not have a partner so that they can bind normal cells in the body and develop an abnormal cell called a tumor and / or cancer. ${ }^{2}$ The binding of free radicals with normal cells in the body can be prevented by the presence of antioxidant ingredients. This antioxidant material can reduce free radicals so as to prevent binding with normal cells. Apart from chemicals, these antioxidant ingredients can also be obtained from natural ingredients. The government program for Back to Nature can be encouraged to find Indonesian endemic plants that contain secondary metabolites as a preventative and curative basis for disease.

Dengen (Dillenia serrata) is one of Indonesia's endemic plants that can only be found on the island of Sulawesi and its surroundings, especially in the area of Luwu Regency. Utilization of this plant is still limited to the fruit, which has been made in addition to juice and sour taste in cooking, has also been developed into dodol. Other parts of dengen plants that potentially contain secondary metabolites of polyphenols are the bark. Utilization of bark in the community, usually cooked with water, and drunk for patients with vomiting blood. ${ }^{3-5}$ This is supported by the large content of polyphenols in dengen stem bark ethanol extract that is equal to $444.8 \mathrm{mg} \mathrm{GAE} / \mathrm{g}$ or $44.48 \% .^{6}$ Seeing the use and content of dengen stem bark above, the researchers will examine the ability of dengue skin ethanol extract in counteracting free radicals. The formulation of the problem in this research is how much is the ability of dengue stem ethanol extract in counteracting free radicals.

\section{MATERIALS AND METHODS}

The study was conducted in July - December 2019 at the Laboratory of Chemistry, Department of Pharmacy, Poltekes Ministry of Health, Makassar. The tools used are maceration vessels, analytical scales, rotary evaporators, glassware, UV-Vis spectrophotometers. While the ingredients used are dengen bark, $70 \%$ ethanol, $96 \%$ ethanol, DPPH, Vitamin C. Selected good stem bark, then washed with running water. The part is made dry simplicia. Dillenia serrata stem bark that has been pollinated is weighed and put into a maceration container, then added $70 \%$ ethanol until completely submerged. The extraction process is carried out for 5-6 days accompanied by stirring so that the extraction process is perfect. Filtering is done, if the solvent has been colored then the solvent is always replaced. The filtering results are evaporated to obtain a thick extract. Extraction was carried out 3 times.

\section{Determination of antioxidant activity}

\section{Making DPPH 40 ppm Solution}

A $40 \mathrm{ppm}$ DPPH solution is made by weighing as much as $40 \mathrm{mg}$ DPPH dissolved in $96 \%$ ethanol to $1000 \mathrm{~mL}$. 


\section{Making a Standard Curve}

As much as $4.0 \mathrm{~mL}$ of a $40 \mathrm{ppm}$ DPPH solution was added with 1.0 $\mathrm{mL}$ of $96 \%$ ethanol to the vial, then the absorbance was measured in the wavelength range of $400 \mathrm{~nm}-800 \mathrm{~nm}$. Obtained maximum wavelength at $516 \mathrm{~nm}$.

3. Manufacture and measurement of Vitamin C solutions

Weighed $500 \mathrm{ppm}$ standard vitamin $\mathrm{C}$ as much as $50 \mathrm{mg}$ and was dissolved with $96 \%$ ethanol to $100 \mathrm{~mL}$. A dilution series of Vitamin C solution was made from stock solutions which were 5 ppm, 10 ppm, 15 ppm and $20 \mathrm{ppm}$. Each concentration series was carefully piped as much as $1.0 \mathrm{~mL}$ and each of them was added $4.0 \mathrm{~mL}$ of a $40 \mathrm{ppm}$ DPPH solution to the vial. The solution was incubated for 30 minutes, then the absorbance was measured at a wavelength of $516 \mathrm{~nm}$.

\section{Preparation of test solutions}

Each extract extracted from the extracted replication was weighed carefully as much as $200 \mathrm{mg}$ of the extract was put into a $20 \mathrm{ml}$ volumetric flask diluted with $96 \%$ ethanol and sufficient to the mark (10,000 ppm). Then piped stock solutions as much as $1 \mathrm{ml}$, $2 \mathrm{ml}, 3 \mathrm{ml}, 4 \mathrm{ml}$, and $5 \mathrm{ml}$, put into a $10 \mathrm{ml}$ volumetric flask and sufficient volume with $96 \%$ ethanol to the mark, so that the solution is obtained with a concentration of $10 \mathrm{ppm}, 20 \mathrm{ppm}, 30 \mathrm{ppm}, 40$ ppm and $50 \mathrm{ppm}$.

Each concentration series was carefully piped as much as $1.0 \mathrm{~mL}$ and each of them was added $4.0 \mathrm{~mL}$ of a $40 \mathrm{ppm}$ DPPH solution to the vial. The solution was incubated for 30 minutes, then the absorbance was measured at a wavelength of $516 \mathrm{~nm}$.

\section{Data analysis}

IC50 value is obtained by linear regression equation which states the relationship between extract concentration with the $\mathrm{x}$-axis and the percent radical capture as the y-axis. \% sample binding / inhibition of free radicals (DPPH solution). The percentage of free radical binding is calculated by the formula:

$$
\% \text { Inhibition }=\frac{\text { absorban blanko-absorban sampel }}{\text { absorban blanko }} \times 100 \%
$$

After obtaining the percentage of inhibition of each concentration, then the equation $y=a+b x$ is determined by calculating a linear regression where $\mathrm{x}$ is the concentration (ppm) and $\mathrm{y}$ is the percentage of inhibition (\%). Antioxidant activity is expressed by $50 \%$ inhibition concentration or IC50, which is a sample concentration that can reduce DPPH radicals by as much as $50 \%$. IC50 values obtained from the value of $x$ after replacing $y=50$. From the equation $y=a+b x$ IC50 values can be calculated using the formula:

$$
\text { IC50 }=\frac{50-A}{B}
$$

\section{RESULT}

From this study, the following data were obtained (Tables 1 and 2).

\section{DISCUSSION}

In this study, the determination of the ability to bind free radicals from Dengen stem bark ethanol extract (Dillenia serrata) originating from the Malangke area of Luwu Regency Indonesia by using a UVVis spectrophotometer. This plant is an endemic plant (Figures 1-3), which only grows in the Sulawesi islands. This plant contains many

Table 1: IC50 values of Vitamin C.

\begin{tabular}{cccc}
\hline Concentration (ppm) & Absorbant & \% Inhibitor & $\mathrm{IC}_{50}$ \\
\hline DPPH & 0.82082 & & \\
5 & 0.71528 & 12.85787 & \\
10 & 0.55297 & 32.632 & $15.488 \mathrm{ppm}$ \\
15 & 0.44655 & 45.59709 & \\
20 & 0.27095 & 66.99033 & \\
\hline
\end{tabular}

Source: Primary Data 2019

\begin{tabular}{|c|c|c|c|c|c|}
\hline $\begin{array}{l}\text { Extraction } \\
\text { Replication }\end{array}$ & $\begin{array}{c}\text { Concentration } \\
\text { (ppm) }\end{array}$ & Absorbant & $\%$ Inhibitor & $I_{50}(p p m)$ & $\begin{array}{l}\text { Average } \\
I C_{50}(\mathrm{ppm})\end{array}$ \\
\hline \multirow{5}{*}{ I } & 10 & 0.76460 & 6.849248 & \multirow{5}{*}{48.53} & \multirow{15}{*}{48.33} \\
\hline & 20 & 0.67078 & 18.27928 & & \\
\hline & 30 & 0.57209 & 30.30262 & & \\
\hline & 40 & 0.48560 & 40.83965 & & \\
\hline & 50 & 0.40231 & 50.98682 & & \\
\hline \multirow{5}{*}{ II } & 10 & 0.76421 & 6.896762 & & \\
\hline & 20 & 0.66624 & 18.83239 & & \\
\hline & 30 & 0.56981 & 30.5804 & 48.20 & \\
\hline & 40 & 0.48576 & 40.82016 & & \\
\hline & 50 & 0.39767 & 51.55211 & & \\
\hline \multirow{5}{*}{ III } & 10 & 0.75781 & 7.67647 & \multirow{5}{*}{48.27} & \\
\hline & 20 & 0.65778 & 19.86306 & & \\
\hline & 30 & 0.54856 & 33.16927 & & \\
\hline & 40 & 0.47065 & 42.661 & & \\
\hline & 50 & 0.41500 & 49.4408 & & \\
\hline
\end{tabular}

Table 2: IC50 values of Dengen Stem Bark Ethanol Extract.

Source: Primary Data 2019 

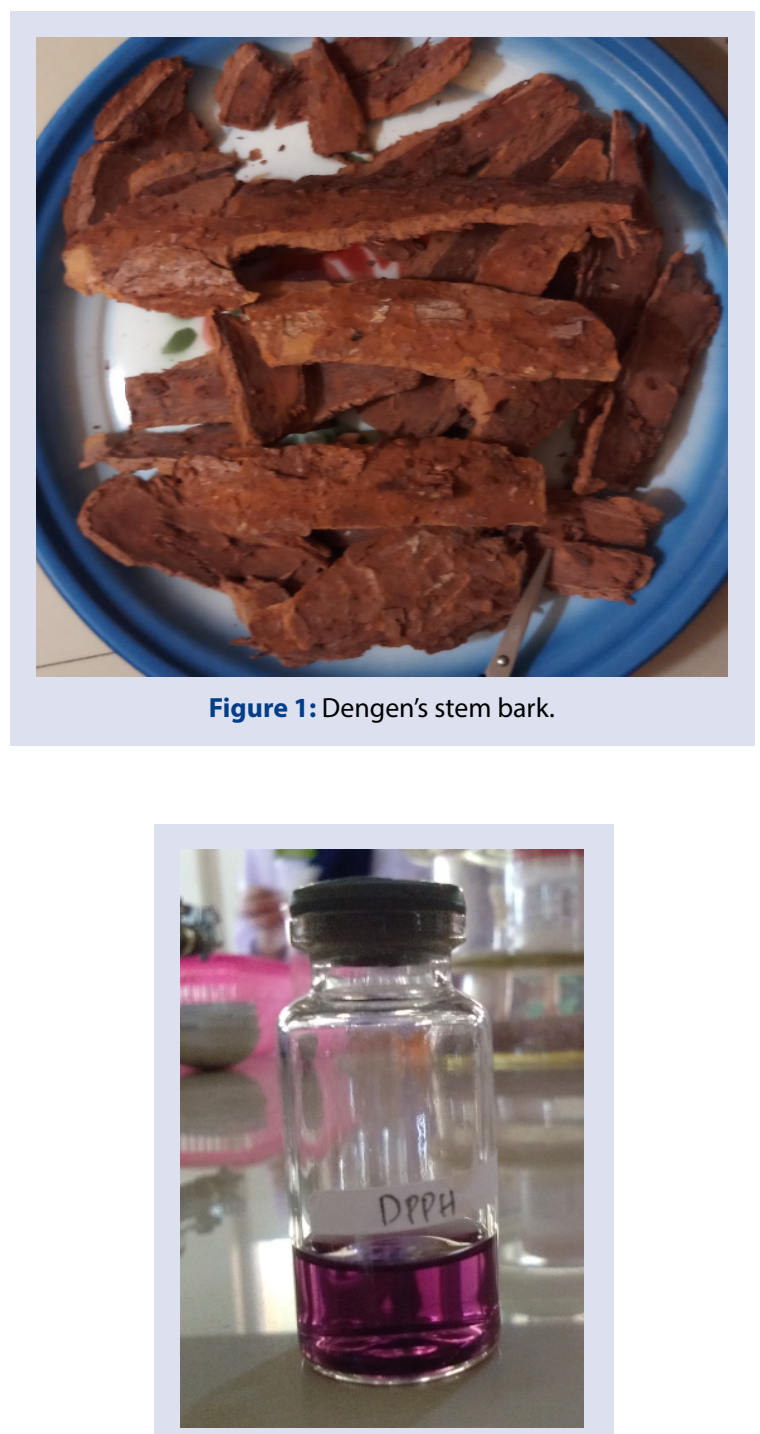

Figure 2: DPPH solution.

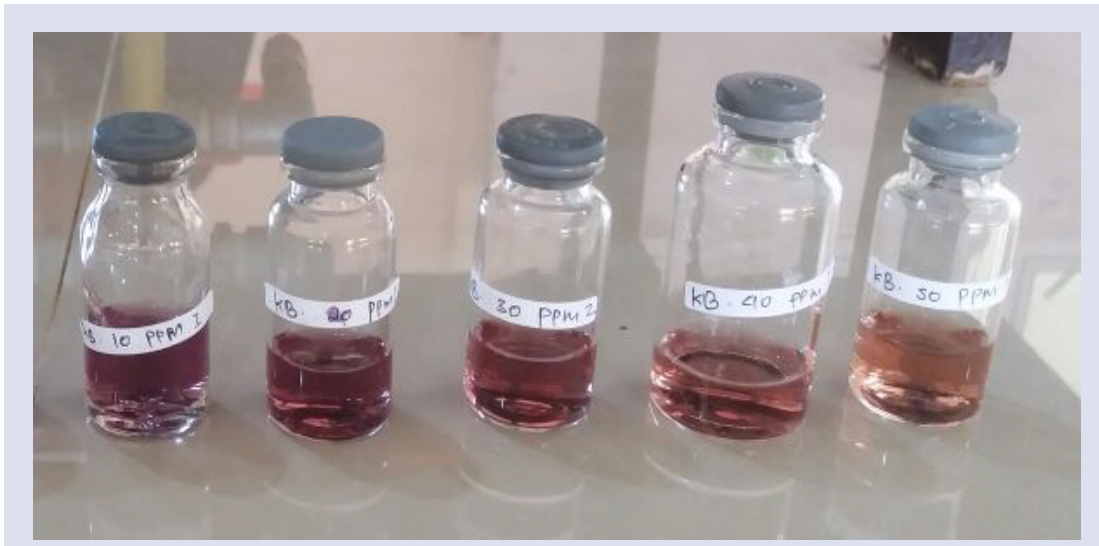

Figure 3: Dengen's stem bark extract to DPPH solution. 
secondary metabolites. Based on the use of the bark by the community as a medicine to vomit blood, while the fruit is usually eaten directly. But because of its sour taste, people use it as an acidic ingredient in food, for example in fish cooking. Based on this utilization, the ability to bind free radicals from the bark is examined. ${ }^{2}$

The use of dengen plants as a medicine to vomit blood was allegedly due to the content of polyphenol compounds. Polyphenol compounds are useful for human health because they have antioxidant properties, free antiradical, anticarogenogenic, and antimicrobial properties so that they can inhibit food pathogens, antiproliferation and antimutagenic, can inhibit the oxidation of low density cholesterol compounds (LDL) on endhothelial cells, can increase high-density cholesterol (antiproliferation and antimutagenic), can inhibit the oxidation of low density cholesterol compounds (LDL) HDL), and can reduce triglyceride content. These polyphenol compounds will be responsible for the antioxidant activity of these parts. The higher levels of polyphenol compounds contained, the higher the antioxidant activity of these parts. In a previous study, ${ }^{3}$ the total polyphenol content of dengen bark extract ethanol extract was $444.8 \mathrm{mg} \mathrm{GAE} / \mathrm{g}$ or $44.48 \%$.

Determination of the ability to bind to free radicals is expressed as an antioxidant activity. Potential antioxidant activity in vitro is carried out using DPPH reagents. The ability to bind to free radicals is illustrated by the reduction in color intensity of DPPH. DPPH has a purple color. The less intensity of the purple color, the higher the ability to bind free radicals. This measurement is carried out at a maximum wavelength of $516 \mathrm{~nm}^{4}$

DPPH is a stable free radical. The principle of this antioxidant activity is the occurrence of a hydrogen or electron donation process that reduces DPPH to diphenyl picrilhydrazine which is no longer radical. This change is seen in the intensity of the DPPH color changing from purple to yellow (pikril group). The change in DPPH color intensity is proportional to the number of electron donations followed by a decrease in DPPH absorbance in the wavelength range of $515 \mathrm{~nm}-520$ $\mathrm{nm}$. Absorption reads on the spectrophotometer at Wavelength 516 illustrate the remaining DPPH molecules contained in the solution.
The parameter that states antioxidant activity by free radical scavenging method from DPPH is IC50. IC50 is a concentration of a test compound that can reduce free radicals by as much as $50 \%$. The smaller the IC50 value, the higher the free radical scavenging activity. IC50 values obtained from a linear regression equation that states the relationship between the concentration of the test compound with percent antioxidant activity.

From the research results obtained by IC50 from dengen stem bark extract has an IC50 value of $48.33 \mathrm{ppm}$. While vitamin C has an IC50 of $15,488 \mathrm{ppm}$. From these results it shows that the color of the skin of the stem has the highest antioxidant activity, which with a concentration of $48.33 \mathrm{ppm}$ has been able to ward off free radicals at half its concentration.

\section{CONCLUSION}

Dengen stem bark extract (Dillenia serrata) has the ability to bind to free radicals with an IC50 value of 48.33 ppm while vitamin C has an IC50 of 15,488 ppm.

\section{REFERENCE}

1. Hasniarti. Studi Pembuatan Permen Buah Dengen. Skripsi. Makassar: Program Studi Ilmu Dan Teknologi Pangan, Jurusan Teknologi Pertanian Fakultas Pertanian. Universitas Hasanuddin Makassar. 2012

2. Ilma N. Studi Pembuatan Dodol Buah Dengen (Dillenia SerrataThunb). Skripsi. Makassar: Teknologi Pangan, Fakultas Pertanian. Universitas Hasanuddin. 2012

3. Jalil J. Inhibitory Effect of Triterpenoids from Dillenia serrate (Dilleniaceae) on Prostaglandin E2 Production and Quantitative HPLC Analysis of Its Koetjapic Acid and Betulinic Acid Content. Journal Molecules. 2015.

4. Kementerian Kesehatan RI. Buletin Jendela Data dan Informasi Kesehatan Penyakit Tidak Menular, Jakarta. 2012.

5. Molyneux P. The Use of The Stable Free Radical Diphenylpicryl-hydrazil (DPPH) for Estimating Antioxidant Activity. Songklanakarin J Science Technology. 2004;26(2):212.

6. Sinala, S, Ibrahim I, Salasa AM. Profile total polyphenol of the ethanol extract from Dengen (Dillenia Serrata) leaf and stem bark which comes from Malangke City Luwu District. Proceeding International Conference, ICUH, Makassar. 2009 


\section{GRAPHICAL ABSTRACT}

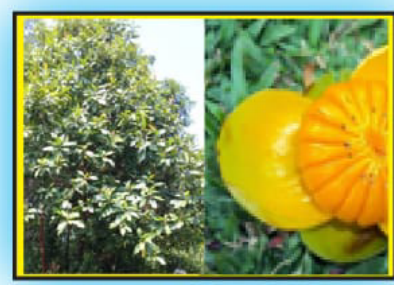

\section{Abstract Graphic}

\section{Dengen's Plants}

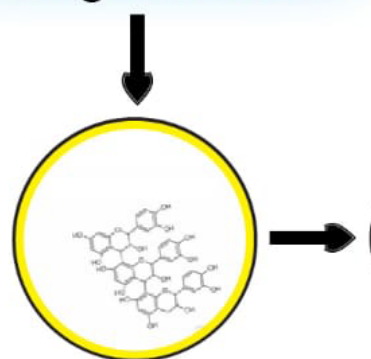

Polyfenol

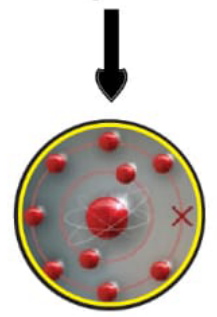

Free radical

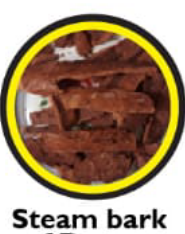
Steam bark
of Dengen

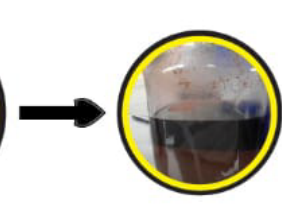

Maceration Methode

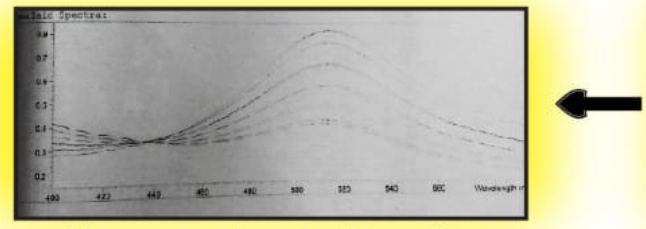

Measure of antioxidant by

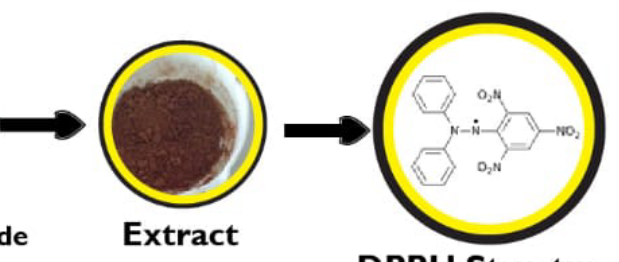

DPPH Structure

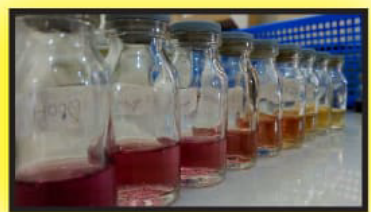

Concentration Series

\section{ABOUT AUTHORS}

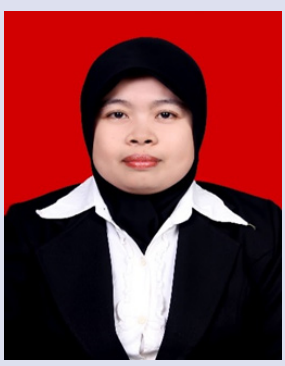

Santi Sinala, S.Si, M.Sc., Apt, was born in Palopo, September 28, 1983. Currently a permanent lecturer in the Department of Pharmacy, Health Polytechnic Makassar of Ministry Health Republic of Indonesia, and teaches several courses in the fields of Pharmacognition and Phytochemistry and Physics Pharmacy. The author is active as a researcher in the field of Pharmacy and productively produces as many as 11 scientific articles that have been journalized. Has produced Phytochemistry textbook, Physics Pharmacy Module (http://bppsdmk.kemkes.go.id/pusdiksdmk/wp-content/ uploads/2017/08/Farmasi-Fisik-Komprehensif.pdf), Physics Practicum Guide that has been in IPR right. Active as an oral speaker at two international conferences.

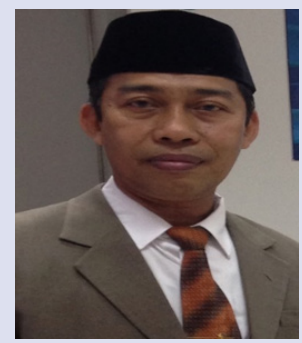

Drs. H. Ismail Ibrahim, M. Kes, Apt, born in Barru, February 2, 1965. Currently as Chair of the Department of Pharmacy, Health Polytechnic Makassar of Ministry Health Republic of Indonesia, is active as a permanent lecturer in Community Pharmacy and as a researcher and actively produces several scientific papers along with the first author. There have been 7 research papers in the last 5 years. 


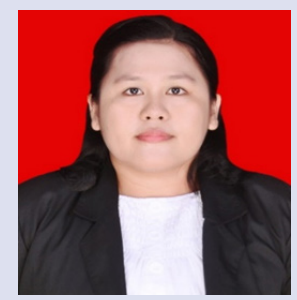

Alfrida Monica Salasa, S.Si, M.Kes. Born in Ujung Pandang, April 1, 1981. Currently active as a permanent lecturer in the field of Pharmaceutical Biology, Microbiology and Parasitology in the Department of Pharmacy, Health Polytechnic Makassar of Ministry Health Republic of Indonesia. Active as a researcher in the field of research in Phytochemical Microbiology and produced about 10 titles of scientific work in the last 5 years. In addition, it has produced 2 works of books namely Microbiology and Parasitology Textbooks and Text Analysis Practical Chemistry Textbooks.

Cite this article: Sinala S, Ibrahim I, Salasa AM. The Ability Free Radical Binding of Dengen's Stem Bark Extract (Dillenia serrata) From Luwu District Indonesia. Pharmacogn J. 2020;12(6):1340-5. 